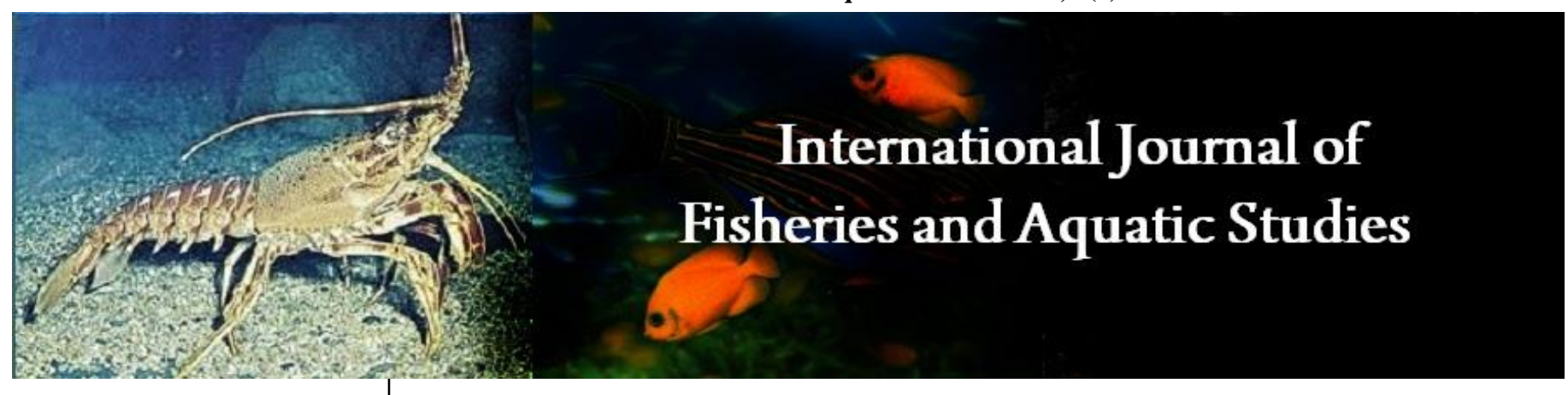

E-ISSN: 2347-5129

P-ISSN: 2394-0506

(ICV-Poland) Impact Value: 5.62

(GIF) Impact Factor: 0.549

IJFAS 2020; 8(6): 16-18

(C) 2020 IJFAS

www.fisheriesjournal.com

Received: 08-09-2020

Accepted: 12-10-2020

Marco F De Guzman

Aurora State College of

Technology, Casiguran, Aurora,

Philippines

Geronimo R Rosario

Pangasinan State University-

Binmaley Campus, Binmaley,

Pangasinan, Philippines

\section{Length-weight relationships of marine fishes caught by danish seine in Lingayen gulf}

\section{Marco F De Guzman and Geronimo R Rosario}

\author{
DOI: https://doi.org/10.22271/fish.2020.v8.i6a.2353
}

\begin{abstract}
The length-weight relationship were analysed for each marine fishes caught by Danish Seine, using specimens collected from the Magsaysay Market, Dagupan City, Pangasinan. Two Sampling sites were selected, namely, Sector I (western Coast) and Sector III (eastern Coast). Two commercial fishing vessels were utilized in the study; one each in Sector I and Sector III. Sampling was done every 15 days for a period of two months. The length-weight relationship, determined by the regression analysis were evaluated for each major fishes. In Sector I, the length and weight relationship for Decapterus macrosoma, Sphyraena barracuda, Rastrelliger kanagurta, Decapterus kurroides and Nemipterus bathybius was growing in a negative allometric way except of the Rastrelliger kanagurta that grows in positive allometric way. In Sector III species of Saurida tumbil, Rastrelliger brachysoma, Trichiurus lepturus, Nemipterus bathybius and Sphyraena barracuda) Sector III grows in negative allometric way. In addition, most of the species shows a strong positive correlation this indicates that as the length increases, weight also increases.
\end{abstract}

Keywords: Length-weight relationship, allometric way, lingayen gulf, danish seine

\section{Introduction}

The size-weight relationship has been used in fishery analyses for several purposes: to convert one variable to another, to estimate the expected weight for a certain size of fishes ${ }^{[1]}$. Fish can attain either isometric growth, negative allometric growth or positive allometric growth. Isometric growth is associated with no change of body shape as an organism grows. Negative allometric growth implies the fish becomes more slender as it increase in weight while positive allometric growth implies relatively stouter or deeper-bodied as it increases in length ${ }^{[2]}$.

The LWR of fishes is useful in assessing the relative well-being of the fish population. It is important in estimating the standing stock biomass, and comparing the ontogeny of fish population from different regions ${ }^{[3]}$. Length-weight relationship parameters are often used as an indicator of fatness and general well-being or of gonad development of fish and are useful for between region comparisons of life histories of a specific species ${ }^{[4,5]}$.

Lingayen Gulf is one of the major fishing grounds of the Philippines located in the northwestern part of Luzon. It lies within $16^{\circ} 00^{\prime} \mathrm{N}$ and $16^{\circ} 40^{\prime} \mathrm{N}$ latitudes and $119^{\circ} 55^{\prime} \mathrm{E}$ and $120^{\circ} 25^{\prime}$ E longitudes. It is bounded on the west and south of Pangasinan province and northeast by La Union province. The gulf covers a total area of $2,085 \mathrm{~km}^{2}$ with a $160 \mathrm{~km}$ coastline from Cape Bolinao to Poro Point and generally shallow with depths of less than $90 \mathrm{~m} .{ }^{[6]}$. The gulf is one of the primary sources of livelihood of the people particularly those living in the coastal areas. Despite the usefulness of length-weight relationship in fisheries science and the importance of the Lingayen Gulf to the livelihood of the people, information about the length-weight relationships and condition factors of major fish species in Sector I and III are non-existent. The paucity of these information propelled this study, which to also provide useful information for better management of the gulf.

\section{Materials and Methods}

This study employed a descriptive-survey method of research. Every 15 days, catch landings of Danish seines from Sectors I and III in Lingayen Gulf were monitored and recorded. The species composition and volume of catches were determined for every landing. Specimens were derived from Magsaysay Market, Dagupan City, Pangasinan where the Danish seines
Marco F De Guzman

Aurora State College of

Technology, Casiguran, Aurora,

Philippines 
operators landed their catch. Danish seine operators served as cooperators and the sources of catch samples. Moreover, only the major species that was based on the record of the secretary" were measured. Two Danish seine vessels were operated in the two sectors; one each in Sector I and Sector III.

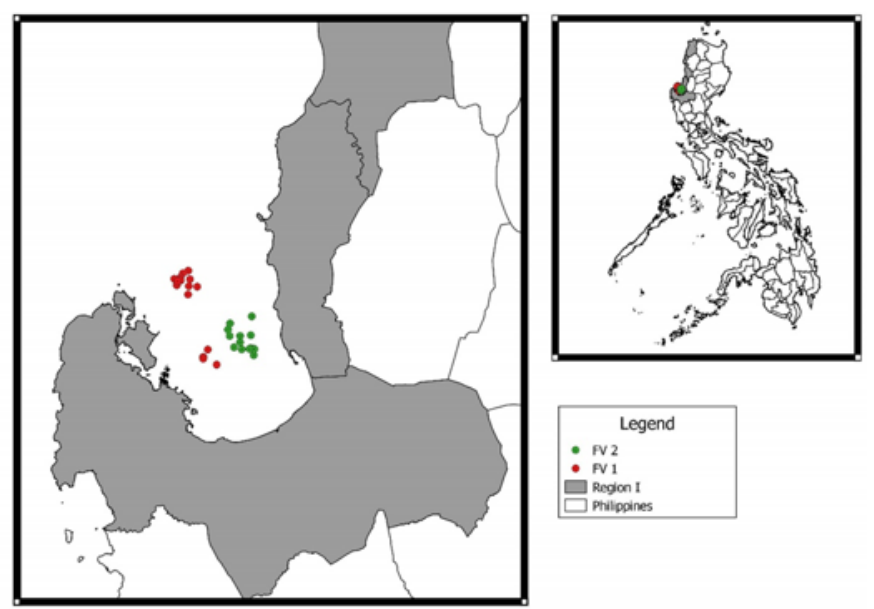

Fig 1: Map showing the fishing areas of Danish seine fishing vessels in Lingayen Gulf.

The total length (TL) of individual fish were measured to the nearest $0.1 \mathrm{~cm}$ using measuring board and weighed to the nearest $0.5 \mathrm{~g}$ using top loading balance $(500 \mathrm{~g}$ and $10 \mathrm{~kg}$ max). The length-weight relationship (LWR) of fishes was estimated using the equation:

$\mathrm{W}=\mathrm{a}^{*} \mathrm{Lb}$

where: $\mathrm{W}=$ weight $(\mathrm{g}), \mathrm{L}=$ total length $(\mathrm{cm}), a=$ constant, $b=$ growth exponent. A logarithmic transformation was used to make the relationship linear ${ }^{[7]}$.

$\log W=\log a+b \log L$

The LWR parameters $a$ and $b$ as well as the coefficient of determination ( $\mathrm{r} 2)$ were derived from least squares regression [6]. The slope $(b)$ was used to describe the three dimensional growth of fish in length, width, and depth. If $b=3$, growth is isometric, if $b<3$, it is negative allometric and if $b>3$, it is positive allometric.

\section{Results and Discussion}

A total of 1,137 individuals belonging 6 genera and 8 species were examined. In Sector I, the length and weight relationship for Decapterus macrosoma, Sphyraena barracuda, Rastrelliger kanagurta, Decapterus kurroides and Nemipterus bathybius was growing in a negative allometric way except of the Rastrelliger kanagurta that grows in positive allometric way. In Sector III species of Saurida tumbil, Rastrelliger brachysoma, Trichiurus lepturus, Nemipterus bathybius and Sphyraena barracuda) Sector III grows in negative allometric way. This implies that majority of the major fishes caught in Lingayen Gulf exhibited low well-being.

Table 1: Parameters of the length and weight of 8 marine species in Lingayen Gulf.

\begin{tabular}{|c|c|c|c|c|c|c|c|c|}
\hline \multirow[t]{2}{*}{ Family } & \multirow[t]{2}{*}{ Scientific Name } & \multirow{2}{*}{$\begin{array}{l}\text { Lingayen Gulf } \\
\text { (Sector I or III) }\end{array}$} & \multirow{2}{*}{ n } & \multicolumn{3}{|c|}{ LIWR } & \multicolumn{2}{|c|}{ Length } \\
\hline & & & & a & b & $\mathrm{r}^{2}$ & $\min$. & $\max$. \\
\hline \multirow[t]{2}{*}{ Carangidae } & Decapterus kurroides & Sector I & 72 & 0.029 & 2.640 & 0.899 & 15.5 & 25.5 \\
\hline & Decapterus macrosoma & Sector I & 119 & 0.045 & 2.410 & 0.713 & 11.3 & 20.3 \\
\hline \multirow{2}{*}{ Scombridae } & Rastrelliger kanagurta & Sector I & 140 & 0.004 & 3.299 & 0.914 & 17 & 25.4 \\
\hline & Rastrelliger brachysoma & Sector III & 121 & 2.193 & 1.278 & 0.289 & 13.3 & 31.1 \\
\hline \multirow[t]{2}{*}{ Sphyraenidac } & \multirow{2}{*}{ Splyraena barracuda } & Sector I & 111 & 0.030 & 2.487 & 0.840 & 29 & 126.7 \\
\hline & & Sector III & 72 & 1.659 & 1.377 & 0.891 & 19 & 39.4 \\
\hline Synodontidae & Saurida tumbil & Sector III & 144 & 0.266 & 1.960 & 0.790 & 15.5 & 47 \\
\hline Trichiuridae & Trichiurus lepturus & Sector III & 93 & 683.4 & $\cdot 0.61$ & 0.504 & 12.2 & 69 \\
\hline \multirow[t]{2}{*}{ Nemipteridae } & \multirow{2}{*}{ Nemipterus bathybius } & Sector I & 139 & 0.014 & 2.967 & 0.927 & 13.7 & 27.3 \\
\hline & & Sector III & 126 & 0.087 & 2.311 & 0.953 & 12.3 & 25.5 \\
\hline
\end{tabular}

${ }^{[8]}$ pointed out that the coefficient $b$ in the LWR of fishes usually ranged from 2.5 to 3.5 . In this study only the species of Decapterus kurroides, Rastrelliger kanagurta and Nemipterus bathybius falls within the range. The low value of $\mathrm{b}$ for the majority of species evaluated was due to low sample size and narrow size which was only represented by medium size individuals. However, the value of $b$ for Rastrelliger kanagurta remains unclear since the other species $N$. bathybius and D. kurroides displayed b value close to 3.0 despite all of the species had relatively sufficient sample size. In terms of the coefficient of determination $\left(r^{2}\right)$, majority of the species examined attained the values of over 0.80 . This indicates highly significant relationships of length to weight of fishes under study. Further studies of similar nature and some biological aspects of commercially important species are necessary to support the formulation of policies for sustainable utilization and appropriate management of fisheries resources in the Gulf.

\section{Conclusion and Recommendation Conclusion}

Decapterus macrosoma, Sphyraena barracuda, Rastrelliger kanagurta, Decapterus kurroides and Nemipterus bathybius was growing allometrically. It appeared that the dominant fish species caught in Sector I is growing in a negative allometric way except of the Rastrelliger kanagurta that grows in positive allometric way. The dominant species (Saurida tumbil, Rastrelliger brachysoma, Trichiurus lepturus, Nemipterus bathybius and Sphyraena barracuda) caught in Sector III grows in negative allometric way. This suggests that the weight is slower than length growth. 


\section{Recommendation}

1. There should be a detail study on length-weight relationship and biology of all fish species in the gulf.

2. Year round data should be collected to have clear understanding on the biology of fishes.

3. Further study is needed on those fishes with small catch rates.

\section{References}

1. Pinheiro MAA, Fransozo A. Análise da relação biométrica entre o peso e a largura da carapaça para o siri Arenaeus cribrarius (Lamarck, 1818) (Crustacea, Portunidae). Archives of Biology and Technology 1993;36(2):331-341.

2. Riedel R, Caskey LM, Hurlbert SH. Length- weight relations and growth rates of dominant fishes of the Salton Sea: implications for predation by fish-eating birds. Lake and Reservoir Management 2007;23:528-535.

3. Petrakis G, Stergiou KI. Weight-length relationships for 33 fish species in Greek waters. Fisheries Research, 1995;21(3, 4):465-469. DOI: 10.1016/01657836(94)00294-7 The Palawan Scientist, 10: 1728 () 2018, Western Philippines University 28

4. Le Cren ED. The length-weight relationship and seasonal cycle in gonad weight and condition in the perch (Perca fluviatilis). Journal of Animal Ecology 1951;20:201-219.

5. Wotton RJ. Ecology of Teleost Fishes. Chapman and Hall, London, UK 1990, 117-158.

6. Silvestre GT, Hilomen VV. Status of Lingayen Gulf fisheries- a brief update, 285-291. In Department of Agriculture-Bureau of Fisheries and Aquatic Resources. In turbulent seas: The status of the Philippine Marine Fisheries. Coastal Resource Management Project, Ricker, W.E. 1973. Linear regression in fisheries research. Journal Fisheries Research Board Can. 2004;30:409-34. Cebu City, Philippines. 378 p.

7. Carlander KD. Handbook of Freshwater Fishery Biology. The Iowa State University Press, Ames, Iowa, USA $1969,752$. 